\title{
The effect of marketing expenses on car sales - an empirical analysis
}

\author{
Mihaela Brînduşa Tudose $^{1^{*}}$, Lidia Alexa ${ }^{2}$ \\ 1"'Gheorghe Asachi” Technical University, Iasi, brindusa.tudose@tuiasi.ro, Romania \\ "'Gheorghe Asachi" Technical University, Iasi, lidia.alexa@tuiasi.ro, Romania
}

\begin{abstract}
The paper assesses empirically the relationship between marketing expenditures and sales in a highly competitive industry, namely automotive, by analyzing the marketing expending of Automobile Dacia S.A. The first part of the paper presents the state-of-the-art and discusses the studies previously conducted which focus on the structure, dynamic and the impact of marketing expenses, while the second part consists in an empirical analysis conducted on Automobile Dacia S.A. marketing spending. The results of the study show that the company managed to increase its' market share by adopting differentiated marketing for each geographical area. Although the research revealed that the allocation percentage from sales for marketing spending is relatively low $(5-6 \%)$, the analysis conducted on the cost per unit sold reveals a share of $3 \%$ on marketing spending.
\end{abstract}

\section{Introduction}

In the context of globalization and increased competitive pressure, the client becomes the most valuable asset for the company and so it needs to valorize the competitive advantage in order to ensure not only maximizing client satisfaction but also profit growth. Consequently, the consumer centered approach needs to be conceived and implemented to guarantee increased company performance and profitability.

Rethinking and implementing the marketing strategy in accordance with specific client profiling requires continuous investments and while the marketing costs have a high degree of certainty, the extensive studies conducted on the impact of the marketing efforts on performance metrics such as revenue, sales, profits or firm value reveal a high degree on uncertainty. Most relevant are S. Srinivasan, K. Pauwels, D. M. Hanssens and M. G. Dekimpe's [1] paper discussing marketing efforts impact over revenue, N. Zhou, D. Zhou and M. Ouyang's [2] article analyzing the correlation between marketing expenses and sales, O. Notta and $\mathrm{K}$. Oustapassidis's [3] research regarding the relationship between advertising and profits or M. Singh, S. Faircloth and A. Nejadmalayeri [4] paper discussing the link between marketing expenses and the firms' marketimposed weighted average cost of capital.

The marketing costs volume, dynamic and structure are directly linked to the activities aimed at increasing costumer satisfaction, loyalty and retention. The main benefits of marketing efforts can be evaluated on two levels: 1) direct financial benefits, generated by increased revenue and consequently higher ROI (Return on investment); 2) indirect benefits resulting from costumer portfolio that can be exploited in the future.

The marketing costs versus benefits management has particularities according to the main objective of the company: increasing the customer portfolio, and preserving (loyalty and retention) of existing customers.

According to S. Pete and I. R. Cardos [5], the first objective entails higher investments, as the cost for acquiring new costumers is significantly higher than the one for retaining existing ones, thus, the second objective is often considered more competitive, financial wise.

The fact that marketing is an important activity for enterprises has caused an increase in marketing related expenditure. L. Kosan [6] considers that a higher level of investment in marketing activities in terms of budgeted

\footnotetext{
Corresponding author: brindusa.tudose@tuiasi.ro
} 
amounts will increase the enterprise performance. In terms of technological and internet development, many new opportunities have been created, necessitating the management of the relationship between enterprises and clients. However, D. Krajicek [7] highlights that the ambiguity of the calculation of return on investment has left questions regarding strategic marketing decisions without suitable answers.

A gradually relevant element in conceiving and implementing the marketing strategies in the last decades refers to the fact that the quality of attention/perception to marketing stimuli is in a constant decrease, as costumers lost interest in watching and listening to information coming from advertising. As a consequence, the cost of "buying" attention in the marketplace is constantly rising, namely, nine times in the last two decades, according to T. S. Teixeira [8].

The combination of higher advertising costs and lower attention forces companies and advertisers rethink how they secure their marketing budget and allocate it across different in order to reach their costumers.

The main objective of the paper was to identify the dynamic, structure and impact of marketing efforts over Romanian companies' financial performance by using a hypothetical deductive methodology and combining qualitative and quantitative analysis. In order to reach this objective, the paper addresses the following issues: a brief literature review on marketing spending and an analysis on S.C. Automobile Dacia S.A marketing expenses and their impact. As a consequence, the paper is organized as follows: the second part treats aspects regarding marketing expenses research elements, discussing marketing budgets cots and revenue sources, the third part covers S.C. Automobile Dacia S.A.'s marketing strategies, sales evolution, cost structure and dynamics of its marketing budget. The last section presents the conclusions, limitations and further research directions.

\section{Marketing expenses research elements}

A marketing budget typically covers costs for advertising, promotion and public relations. Each amount varies according to business size, annual sales and competitors marketing activities.

Depending on the specific industry patterns, marketing budgets can range from as low as $1 \%$ of sales to over $30 \%$. New companies can spend as much as $50 \%$ of sales for marketing programs in the first year, depending on the product/services life cycle stage; in the introductory stages the marketing budget being larger.

\subsection{Marketing budget - costs}

A cost represents all the expenses used for acquisition, allocation and consumption of production factors, in order to achieve the productive process and the sale of the goods (commodities and services). M. B. Tudose [9] appreciates that, including the expenses for manufacturing and selling, the cost implies a comparable consumption of factors of production.

The cost (production, marketing, management) occupies a central role in producers' decision making process, as the company seeks to adjust factor inputs to either maximize output at a given cost or minimize cost for a determined level of production. The central concern of the company is to associate the sale price of the manufactured item with an offer at a cost that will allow it to obtain the highest profit. Marketing costs include all the costs related to delivering the goods or services to customers. According to the Business Dictionary [10], the most relevant marketing expenses refer to: the costs of transferring the title of goods to the client, storing the goods until delivery, advertising costs or distribution to the point of sale. In other words, marketing costs include expenses related to the development, sale and distribution of goods and / or services.

In terms of marketing costs overall value, research by J. A. Weber [11], reveals the following results: marketing costs have registered a rapid increase from only $20 \%$ (after 1950s) to over $50 \%$ in the early 2000s. This significant upsurge in marketing costs combined with the increased pressure from stakeholders, forces managers to better validate each sum spent on marketing activities and to find ways to show how marketing expenditure adds to shareholder value. As a result, marketing managers have to implement strategies to enhance the efficiency of marketing efforts, respectively, to increase marketing productivity. The first category of strategies managers can use focuses on increasing efficiency by reducing costs. The second category emphases the methods to estimate the potential Return on Investment for different marketing scenarios / alternatives combined with adjusting the marketing budget in order to contribute to increasing the overall value of the company.

In terms of spending, the marketing budget can include an array of activities, depending on the profile of the company in case. The overall marketing budget can incorporate costs for printing and broadcasting advertising materials, designing and printing for all types of materials, such as newsletters, brochures and press releases, direct mail costs, website development and maintenance, public relations activities, organization of trade shows or any other special events needed etc.

Another classification of marketing related activities is offered by S. Hardesty and P. Leff [12] who studied the direct marketing approach and developed three main categories of marketing activities: packing and storage, transportation, and selling and administration.

The first step in evaluating the marketing costs consists in identifying the relevant marketing activities included in the company's marketing strategy and plans. Once the list is created, the next stage refers to group the activities on categories and determine the resources needed for implementation: human, material and financial. The resources consumption value will

*Corresponding author: brindusa.tudose@tuiasi.ro 
represent the basis for determining specific costs of marketing activities.

\subsection{Marketing budget - revenue sources}

Another important step in establishing the marketing budget consists in determining the sources of funding. The marketing literature identifies three main methods that companies use to allocate funds for marketing activities:

1) Percentage-of-Sales is considered to be one of the most commonly used method for founding marketing budgets. Depending on the company size, the average marketing allocations can range between $2 \%$ (for small companies) and $9-12 \%$ (for medium and large companies). For startups or companies launching a new product/service the marketing budgets can be significantly higher in terms of percentage of sales. The main advantage of this specific method refers to the fact that the marketing budget will increase, or decrease, simultaneously with the sales revenue of the company.

2) The Competitive-Parity Method, presented by J. H. Murphy, L. S. DeLewis and I. C. Cunningham [13], correlates the marketing budget with the product/service's market share being also based on analyzing the marketing budgets of competitors and trying to match or outspend their budget.

3) The Objective-and-Task Method is often considered the most effective budgeting method. In this specific case, the marketing budget is based on the company's marketing objectives included in the marketing plan. Compared to the first two methods, this one has the advantage that there is a direct correlation between the budgetary allocation and a specific objective, which allows a better evaluation of ROI, according to J. H. Murphy, L. S. DeLewis and I. C. Cunningham [13].

Regardless of the method used, the final marketing budget needs to cover in detail the company's marketing activities and expenses and the manner to cover those expenses.

\section{Marketing costs analysis for s.c. Automobile dacia s.a.}

In 1999 , Renault acquired $51 \%$ of the capital of the Automobile Plant from Mioveni; today the company owns $99,43 \%$ of the business. Automobile Dacia S.A. is one of the most important companies in Romania with a significant contribution to the gross domestic product. In 2014, Automobile Dacia had the largest turnover in Romania and in the past years, more than $93 \%$ of the company's output is being exported to 34 countries on four continents. Initially, the company's products were categorized as „low-cost” (especially due to Logan and Logan break models); later the products managed to revolutionize the market, especially through Sandero model, being ranked in the medium class (semipremium).
The general marketing strategy of the company is a differentiated one, adjusted according to geographical areas with three specific approaches: on Romanian local market where the brand is leader, the core of the strategy focuses on promoting pride and confidence; in developing countries such as Algeria, Morocco or Turkey the strategy is focused on a more traditional approach, while in Western European saturated markets, Dacia's strategy aims at o more revolutionary approach focused on affordability, under the motto "cross the line, dare".

The overall number of cars sold and the evolution of the market share (on the new cars market) in Romania is presented in Table 1.

Table 1. Automobile dacia s.a. Market Share and Number of Cars Sold

\begin{tabular}{|lllll|}
\hline & $\begin{array}{l}\text { Market } \\
\text { share }\end{array}$ & $\begin{array}{l}\text { Cars sold } \\
\text { Total }\end{array}$ & in Romania & Abroad \\
\hline $\mathbf{2 0 1 6}$ & $31 \%$ & 584.219 & 38.861 & 545.258 \\
\hline $\mathbf{2 0 1 5}$ & $30 \%$ & 550.920 & 36.946 & 513.974 \\
\hline $\mathbf{2 0 1 4}$ & $30 \%$ & 511.465 & 29.625 & 481.840 \\
\hline
\end{tabular}

Source: own processing after the Annual Financial Statements of S.C. Automobile Dacia S.A.

Based on the information included in the Balance sheet we have identified the main categories of marketing expenses of the company (Table 2).

Table 2. The Structure of the Marketing Expenses at Automobile Dacia s. a.

\begin{tabular}{|c|c|c|c|}
\hline & 2014 & 2015 & 2016 \\
\hline $\begin{array}{l}\text { Total marketing } \\
\text { expenses, out of which: }\end{array}$ & 970,8 & 1129,7 & 1307,9 \\
\hline $\begin{array}{l}\text { - collaborators expenses - } \\
\text { research studies }\end{array}$ & 16,2 & 18,8 & 190,0 \\
\hline $\begin{array}{l}\text { - market studies } \\
\text { regarding competition }\end{array}$ & 0,3 & 0,4 & 0,4 \\
\hline $\begin{array}{l}\text { - image research studies - } \\
\text { financial institutions }\end{array}$ & 1,4 & 1,5 & 1,6 \\
\hline - advertising MCX & 100,4 & 129,2 & 125,6 \\
\hline - trades and fairs & 0,4 & 0,8 & 0,7 \\
\hline $\begin{array}{l}\text { - protocol, invitations \& } \\
\text { collaborators }\end{array}$ & 0,4 & 0,5 & 0,5 \\
\hline $\begin{array}{l}\text { public relations, } \\
\text { invitations, receptions }\end{array}$ & 26,6 & 30,9 & 28,7 \\
\hline $\begin{array}{l}\text { - other promotional } \\
\text { channels }\end{array}$ & 0,2 & 0,3 & 0,3 \\
\hline $\begin{array}{l}\text { - transportation services } \\
\text { for buyers }\end{array}$ & 547,5 & 667,1 & 673,1 \\
\hline - sales shipments & 211,3 & 202,5 & 206,3 \\
\hline - collective shipments & 36,9 & 46,6 & 51,0 \\
\hline $\begin{array}{l}\text { - travel expenses sales } \\
\text { representatives }\end{array}$ & 0,6 & 0,7 & 0,6 \\
\hline $\begin{array}{l}\text { - travel expenses delegate } \\
\text { partners }\end{array}$ & 28,6 & 30,4 & 31,1 \\
\hline
\end{tabular}

Source: Own processing after the Balance sheet, December 2016 - S.C. Automobile Dacia S.A.

The information included in table 2 reveal that:

1) most part of the marketing expenses is related to distribution (circa $80 \%$ of the total marketing budget);

2) advertising expenses represent, an average of $10 \%$ of the marketing budget;

3) other expenses (research studies, collaborators, fairs and trades, public relations, delegations) represent 
about $10 \%$ of the total marketing budget. The dynamic analysis of the correlation between the marketing budget and the company's turnover is presented in Table 3 .

Table 3. Marketing budget (share in turnover) and marketing cost per unit

\begin{tabular}{|c|c|c|c|}
\hline Indicators & 2014 & 2015 & 2016 \\
\hline 1. Turnover (mil. RON) & 18833 & 19165 & 22044 \\
\hline 2. Marketing costs (mil. RON) & 970,8 & 1129,7 & 1307,9 \\
\hline $\begin{array}{lccc}\text { 3. } & \text { Marketing } & \text { costs } & \text { as } \\
\text { percentage of sales } & & \end{array}$ & $5,2 \%$ & $5,9 \%$ & $5,9 \%$ \\
\hline 4. No. of cars sold & 511.465 & 550.920 & 584.219 \\
\hline $\begin{array}{l}\text { 5. marketing costs per unit of } \\
\text { product sold (RON/car) }\end{array}$ & 1898 & 2050 & 2239 \\
\hline
\end{tabular}

Automobile Dacia S.A. allocates an average of 5-6\% of sales for marketing activities. Taking into consideration the company's size, one would be tempted to appreciate that this value is insignificant, but interpreting it in terms of unit value and number of sold products, the overview changes considerably. For each sold car, the company spent for marketing activities an average of 2000 RON. At an average value per sold car of 67.500 RON (respectively 15.000 Euro, estimated in accordance with Romanian sales), the marketing expenses represent almost $3 \%$.

The most significant part of this budget is allocated for distribution (shipment) activities.

Overall, the impact of marketing activities is a positive one, as the company has registered constant increase in sales, and consequently market share.

\section{Conclusions}

Globalization and increased competitive pressure forces producers and sellers alike to carefully manage not only their marketing strategies and activities but also the costs entailed by them. This is an increasingly important element, as the costs are specific and have a high degree of certainty, while the benefits can have a higher degree of uncertainty, even under the conditions of a rigorous customer relationship management.

Determining the volume and structure of the marketing budget needs to take into account two types of constraints: the first one refers to the customers and shareholders needs and expectations and the second one to the fact that once the marketing budget is being increased, investors expect proportionally elevated profits.

The differentiated marketing strategy adopted by Automobile Dacia S.A. focusing on different geographical areas proved to be successful as it led to an increased market share for the company.

In terms of marketing costs, the highest amount goes to expenses related to distribution (approximately $80 \%$ of the total marketing budget).
The research revealed that the company allocates an average of $5-6 \%$ of sales for marketing activities; the analysis based on cost per unit sold disclosed that approximately $3 \%$ represent marketing costs.

Taking into consideration the dynamic of the industry and the specificities of the sold goods (cars) - high value and long term use - the strategy to attract new customers involves high marketing budgets.

Research limitations and further directions. The research has a significant limitation due to the fact that the analysis and interpretation of the activity cost structure was done for a single company, but apart from this, the research team considers that the study results are of substantial value and can represent a starting point for future research. We are also considering further studied for identifying the determinant factors of strategies for substantiating marketing budgets of the most important operators in the automotive industry, as well as determining the impact of marketing cost dynamics on the performances of these companies.

\section{References}

[1] S. Srinivasan, K. Pauwels, D.M. Hanssens, M.G. Dekimpe, "Do promotions benefit retailers, manufacturers, or both", in Management Science, Issue 50, 2004, pp. 617-629.

[2] N. Zhou, D. Zhou, M. Ouyang, "Long-term effects of television advertising on sales of consumer durables and nondurables", in Journal of Advertising, issue 32, 2003, pp. 45-54.

[3] O. Notta, K. Oustapassidis, "Profitability and media advertising in Greek food manufacturing industries", Review of Industrial Organization, 18, 2001, pp. 115-126.

[4] M. Singh, S. Faircloth, A. Nejadmalayeri, "Capital market impact of product marketing strategy: Evidence from the relationship between advertising expenses and cost of capital", in Journal of the Academy of Marketing Science 33, 2005, pp. 432-444.

[5] S. Pete, I. R. Cardos, "A managerial and cost accounting approach of customer profitability analysis", in Annals of the University of Oradea, Economic Science Series, 19(1), 2010, pp. 570-576.

[6] L. Kosan, "Accounting for Marketing: Marketing Performance Through Financial Results", in International Review of Management and Marketing, Vol. 4, No. 4, 2014, pp. 276-283.

[7] D. Krajicek, "The ROI of everything, defining a new philosophy of marketing value", in Marketing Insights, Summer/2013, pp. 8-9.

[8] T. S. Teixeira, "The Rising Cost of Consumer Attention: Why You Should Care, and What You Can Do about It", Working Paper 14055, Harvard Business School, 2014, available at http://www.hbs.edu/faculty/ Publication \%20Files/14055_2ef21e7e-7529-4864-b0f0-c64e4169e17f.pdf

[9] M. B. Tudose, Bazele economiei. Microeconomie (suport de curs), 2016, Universitatea Tehnică Gh. Asachi, Iaşi.

[10] http://www.businessdictionary.com/definition/marketing-cost.html

[11] J. A. Weber, "Managing the marketing budget in a costconstrained environment", in Industrial Marketing Management, 31, 2002, pp. $705-717$.

[12] S. Hardesty, P. Leff, "Determining Marketing Costs and Returns in Alternative Marketing Channels", Renewable Agriculture and Food Systems, volume 25, Issue 1, 2010, pp. 24-34.

[13] J. H. Murphy, L. S. DeLewis, I. C. Cunningham, Determining the Advertising Appropriation and Budgeting in Integrated Brand Promotion Management, Kendall Hunt Publishing Company, 2011, pp. 123-165. 